tradycji Wujkowej". Jeżeli przez kilkà wieków to dzieło Wujkowe, owoc żmudnej i jednolitej (jeden tłumacz) karmiło rzesze wiernych i duchownych, to niewątpliwie zasługuje na rzadsze odstępstwo w słownictwie i stylu. On sam pisał: „,... nic ująć, nic dodać, niczego poprawiać", chyba że system obcego języka gwałcił przejrzystość i jasność komunikatywną polszczyzny. I on był ostro atakowany, szczególnie przez swoich konfratrów jezuitów. A był przecież mistrzem słowa polskiego, archaizującym i mającym oko i ucho otwarte na to, co żywe, potoczne w języku.

Wrocław

STANISEAW ROSPOND

\author{
Ks. Ireneusz Pawlak
}

\title{
SPRAWOZDANIE Z OBRAD MUZYKÓW KOŚCIELNYCH
}

W dniach 3-4 września 1981 r. odbyło się w Wyższym Seminarium Duchownym w Sandomierzu sympozjum naukowe Sekcji Muzyki Kościelnej przy Komisji Studiów Episkopatu Polski. Udział w obradach wzięlo 30 członków sekcji. Sesja poświęcona była dwom zagadnieniom: podręcznikowi muzyki kościelnej dla seminariów duchownych w Polsce oraz ogólnopolskiemu śpiewniksowi kościelnemu.

Obrady otworzył przewodniczący sekcji ks. prof. dr hab. K. Mrowiec (KUL). Pierwszy dzień poświęcony był sprawie podręcznika. Wprowadzenia do dyskusji wygłosilii: ks. W. Kądziela, Potrzeba podręcznika muzyki kościelnej dla seminariów duchownych oraz ks. Z. Rogala, Treść podręcznika. Pierwszy referat $\mathrm{w}$ krótkich słowach uzasadnil potrzebę podręczmika, która wynika $z$ obecnego stanu muzyki kościelnej w seminariach duchownych. Podręcznik jest potrzebny tak wykładowcy, jak i alumnom, a także ze względów metodycznych, gdyż brakuje dotąd jednakowej metody prowadzenia zajęć. Ks. Rogala przyjmując jako pewnik potrzebę podręczmika zajął się jego kształtem. Według referenta podręcznik powinien składać się z dwóch części: teoretycznej i praktycznej, gdyż winien zawierać kompendium wiedzy koniecznej do opanowania przez seminarzystow. Szczególną uwage należy przykładać do chorału gregoriańskiego, bowiem materiały do jego nauczania są trudno osiągalne. Koniecznym będzie także opracowamie rysu historyczmego muzyki wielogłosowej ze szczególnym uwzględnieniem muzyki polskiej. Bardzo ważnym zagadnieniem jest również teologiczna podstawa muzyki kościelnej.

Zdaniem referenta, poza wiadomościami o dzwonach, mie ma potrzeby zamieszczania informacji o instrumentach, gdyż można je spotkać w wydawnictwach fachowych. Część praktyczna podręcznika winna zawierać śpiewy liturgiczne dla celebransa, psalmodię, część Liturgii Godzin, repertuar gregoriański przydatny na różne okazje. Należało by także zamieścić polską dyskografię muzyki religijnej.

Pjerwsze głosy w dyskusji koncentrowały się wokół zagadnienia, czy podręcznik ma być przeznaczony przede wszystkim dla alumnów, czy też 
dla wykładowców. Zdecydowana większość dyskutantów (ks. Pasionek, ks. Dworakowski, ks. Bojasiński, ks. Bartkowski, ks. Szygenda, ks. Szachowicz) wypowiadała się za podręcznikiem dla seminarzystów, byleby zawierał całołształt kultury muzycznej Kościoła, zwłaszcza na terenie Polski (ks. Cempura, ks. Bartkowski). Dobrze byłaby jednak uwzględnić bogatą bibliografię poszczególnych działów podręcznika, by w ten sposób mógł on też stanowić pomoc dla wykładowcy (ks. Mrowiec).

Zaproponowano także dwuetapowe przygotowanie podręcznika (ks. Pawlak). Pierwszym etapem byloby wydanie materiałów wprowadzających w kulturę muzyczną Kościoła. Po doświadczeniach i dyskusji można by wówczas przystąpić do redagowania ostatecznej wersji podręcznika. Propozycja, mimo sporadycznych sprzeciwów, spotkała się z uznaniem.

Następnie przystąpiono do tworzenia ram programowych podręcznika. Wobec trudności uzgodnienia stanowisk co do kwestii, czy podręcznik ma zawierać całość wiedzy potrzebnej klerykowi, czy też dziedziny dotąd nieopracowane lub trudno dostępne, przystąpiono na wniosek ks. Mrowca do wytypowanych zagadnień, które nie budzą kontrowersji. Przyjęto następujące grupy tematyczne:

1. Choral gregorianski. 2. Historia religijnej muzyki wielogłosowej. 3. Pieśń kościelna. 4. Kościelne prawodawstwo muzyczne. 5. Akustyka, instrumentoznawstwo, organoznawstwo, dzwony. 6. Emisja głosu, foniatria, dykcja. 7. Zasady muzyki w zarysie. 8. Prowadzenie zespołów instrumentalnych i śpiewaczych.

Następnie przystąpiono do wytypowania komisji, które powinny opracować projekty poszczególnych dzialów. Dokonano wreszcie wyboru przewodniczących poszczególnych komisji. Zostali nimi: 1. ks. I. Pawlak, 2. ks. K. Mrowiec, 3. ks. B. Bartkowski, 4. ks. Z. Rogala, 5. ks. M. Dworakowski, 6. ks. W. Kądziela, 7. ks. K. Pasionek, 8. ks. W. Leśnikowski. Komisje spotkaly się w przerwie obrad, aby w rozmowach roboczych uzgodnić tok pracy.

W drugim dniu zjazdu jedynym wystąpieniem była wypowiedź ks. K. M row c a, Sprawozdanie z prac nad ogólnopolskim śpiewnikiem kościelnym. Po przypomnieniu faktów związanych bezpośrednio z decyzją opracowania śpiewnika prelegent przystąpił do omawiania głównych kwestii: koncepcji śpiewnika, struktury śpiewnika i stanu zaawansowania prac. W koncepcji śpiewnika redakcja przyjęła 3 założenia: śpiewnik winien mieć charakter liturgiczny, oficjalny i wzorcowy. Przy doborze repertuaru powinno się uwzględnić trzy kryteria: wartość teologiczną, liturgiczną i estetyczną melodii. Spiewnik dzielić się będzie na następujące główne części: śpiewy mszalne, śpiewy przy sprawowaniu sakramentów i sakramentaliów, śpiewy związane z Liturgią Godzin, śpiewy związane z nabożeństwami. Datychczasowe prace koncentrowały się nad zebraniem śpiewów procesyjnych mszalnych na poszczególne okresy roku liturgicznego. Do tej pory zebrano 365 pieśni. Nie zostaly jeszcze opracowane śpiewy międzylekcyjne. Referent sygnalizowal też brak pieśni na niektóre święta np. Narodzenia i Nawiedzenia Najśw. Maryi Panny, pieśni do świętych - zwlaszcza polskich, pieśni do Wszystkich Swiętych i in.

W ożywionej dyskusji poparto na ogół tok prac nad śpiewnikiem. Sugerowano jedynie, by poszczególne diecezje dodawały swoje ancksy do śpiewnika (ks. Targoński), bądź téz wydawały swoje śpiewniki, ale z uwzględnieniem repertuaru ogólnopolskiego (ks. Mrowiec).

Prelegent zwrócił się do zebranych $z$ apelem o nadsylanie do redakcji nowych lub mniej znanych a wartościowych pieśni. Postulowano także umieszczenia w śpiewniku tzw. ciemnych jutrzni (ks. Ćwiek), nieszporów za zmarłych (ks. Kądziela) oraz tradycyjnych tekstów psalmów nieszpornych. Stwierdzono wreszcie, że przy dotychczasowym tempie prac pierwsza redakcja śpiewnika winna byé ukończona za dwa lata. 
Zebrani zgodnie uznali konieczność opublikowania tekstu sprawozdania $z$ prac nad śpiewnikiem, by poinformować opinię publiczną o prowadzonych pracach oraz by zyskać jak najwięcej uwag od ludzi tym zagadnieniem zainteresowanych.

Lublin

KS. IRENEUSZ PAWLAK

\section{Jerzy Józef Kopeć $C P$ \\ O. MICHAL STANISLAW STOLARCZYK CP (1916-1981)}

Z grona polskich biblistów powolal Pan do siebie, dnia 26 XII 1931 r., pasjoniste $O$. Michała Stolarczyka. Uroczystości pogrzebowe odbyły się w kościele zakonnym w Przasnyszu, po czym przeniesiono ciało Zmarłego do krypty tej świątyni.

Stanisiaw Stolarczyk urodził sie 12 VII 1916 r. w Jastrząbce k/Przasnysza, z rodziców Franciszka Stolarczyka i jego żony Eleonory z domu Gaska. Po ukończeniu szkoły podstawowej w Woli Błędowskiej i Niższego Seminarium Zakonnego w Przasnyszu wstąpił 14 IX $1934 \mathrm{r}$. do Zgromadzenia Pasjonistów, przyjmując imię Michała od Wniebowzięcia NMP. Pierwszy rok studiów filoz.-teol. odbył w Przasnyszu, a następnie kontynuował je od listopada $1936 \mathrm{r}$. w Studium Generalnym Pasjonistów w Rzymie na Monte Celio. Tu też 16 VI 1940 r. otrzymał́ święcenia kapłańskie i po zakończeniu zwyczajnego kursu seminarynjego podją studia teologii dogmatycznej w Ateneum Dominikańskim "Angelicum”, uwieńczone licencjatem w 1942 r. Zaraz potem zapisał się na Papieski Instytut Biblijny. Profesorami jego byli znani bibliści: Augustym Bea, Albert Vaccari, Augustyn Merk, Stanisław Lyonnet, Urban Holzmeister, Ludwik Semkowski, Maksymilian Zerwick i Alojzy Da Fonseca. Po otrzymaniu w roku 1944 licencjatu z Pisma św. pragnąı O. Michał kontynuować studia biblijne, lecz władze zakonne nie wyrazily na to zgody, noszac się z zamiarem jego rychlego powrotu do Polski. Przez dwa jednak lata (1945-47) wykładal teologię dogmatyczną w domu pasjonistów na Monte Celio i dopiero w 1947 r. powrócił do kraju. Tu obok licznych funkcji zakonnych (mistrz nowicjatu, dyrektor studentów, prefekt studiów i długoletni konsultor prowincjalny) wykłada, w latach 1949-1969 Pismo św. w Zakonnym Seminarium w Przasnyszu.

Mając na uwadze dobrą znajomość przez O. Michała Stolarczyka języka greckiego, hebrajskiego i aramejskiego, O. Augustyn Jankowski powierzył mu korektę niektórych ksiąg Starego Testamentu przy edycji Biblii Tysiaclecia, zaś ks. Michał Peter podobną prace przy przygotowaniu Biblii Poznańsiiej. Dla tej ostatniej edycji przetrumaczył ponadto $z$ j. hebrajskiego na polski psalmy 101-150. Z własnych publikacji 0 . Miehala można wspomnieć 4 artykuły o tematyce biblijnej, ogloszone w j. włoskim i polskim, oraz 9 innych opracowań dotyczacych bliskiej mu duchowości pasyjnej, zwłaszcza związanej z życiem Sługi Bożego O. Bernarda Kryszkiewicza CP (1915-1945). Na uwage zasługuja także cenne prace Zmarłego pozostające w maszynopisie: 8 tomów kroniki z lat 